\title{
Unexpected Discovery: A Guided-Inquiry Experiment on the Reaction Kinetics of Zinc with Sulfuric Acid
}

\author{
Martin Rusek, ${ }^{*} \dagger$ Pavel Beneš, ${ }^{\dagger}$ and John Carroll ${ }^{\ddagger}$ \\ ${ }^{\dagger}$ Department of Chemistry and Chemistry Education, Faculty of Education, Charles University, Magdaleny Rettigové 4, \\ 11639 Praha 1, Czech Republic \\ ${ }^{\ddagger}$ Nottingham Institute of Education, Nottingham Trent University, ABK Building, Clifton Nottingham NG11 8NS, United Kingdom
}

Supporting Information

\begin{abstract}
The role of practical work in the training of student teachers is central to the development of their future pedagogy and practice. However, not all laboratory based activities give sufficient challenge in the development of both cognitive and practical skills. The activity proposed in this paper helps reinforce an understanding of reaction kinetics through a study of the reaction of zinc with sulfuric acid. In this study, the observed reaction kinetics conflicted with the typical expectation, which offered a problem to motivate an inquirybased activity.
\end{abstract}

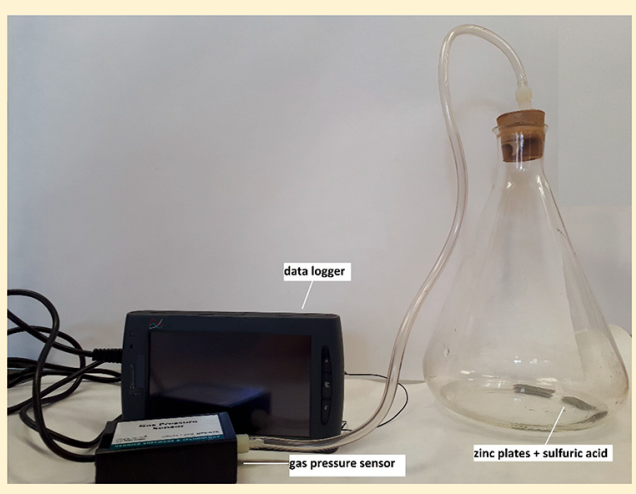

KEYWORDS: Upper-Division Undergraduate, Hands-On Learning/Manipulatives, Inquiry-Based/Discovery Learning, Acids/Bases, Laboratory Instruction

W hile many students studying chemistry at an advanced level can demonstrate a good theoretical subject knowledge, proficiency in undertaking practical work appears to be at a significantly lower level. ${ }^{1,2}$ This could possibly be explained by a reduction in practical work in schools, especially in the form of investigations at both lower and upper-secondary level. ${ }^{3,4}$ The current generation of trainee teachers appears to be testament to this legacy and lack confidence in these essential areas.

Work reported by Rocard supports this observation and describes the dramatic impact of inquiry based education (IBE) on student knowledge and skills. ${ }^{5}$ It would appear that training future teachers in areas such as IBE is an essential factor in the development of their own skills and those of their future students. ${ }^{6}$ Teachers who did not undergo any practical inquirybased sessions during their studies or training tend not include IBE in their lessons. Papers relating to this topic have recently been published in this Journal ${ }^{8-10}$ alongside other journals. ${ }^{11-13}$ In an attempt to build on this work and contribute to the field of experimentation in chemistry education, this paper details a guided-inquiry experiment where trainee teachers assumed the role of school students to:

(1) solve a problem arising from a misconception;

(2) address any misconceptions about the reaction of an acid with a metal.

\section{TOPIC CHOICE}

Misconceptions by students of chemistry and teaching strategies to support their prevention have been a well published area of research in recent years. ${ }^{14-17}$ In addition, several studies appear to indicate that IBE supports a better conceptual understanding of the subject and can help address some of these concerns. ${ }^{18}$ In this work, we have attempted to address a common misconception in relation to acid-metal reaction kinetics. When asked about the factors influencing the rate of reaction, a common answer was that reaction rate increases with the concentration of acid. While this is something often taught by teachers and written in school chemistry textbooks (found by the authors of this paper in Czech, German, and British examples), this misconception proved to be a motivating factor in developing the resource discussed in this paper.

Many undergraduate laboratory experiments focus upon reaction kinetics, ${ }^{19-21}$ the behavior of acids, ${ }^{12,14,22,23}$ and their reaction with metals. ${ }^{10,24-26}$ Often, practical work makes the assumption that students already have a fundamental knowledge of the subject and therefore are not required to explain observations at a simple level. However, in supporting the development of trainee teachers, it is of vital importance that they develop the skills and ability to explain concepts in an appropriate way, at a level accessible to their school students.

To challenge their typical thinking, and additionally support the development of associated pedagogies, an investigation into

Received: May 15, 2017

Revised: March 17, 2018

Published: April 13, 2018 
the reaction kinetics of sulfuric acid reacting with zinc was chosen for this study.

Further information related to the properties and products of this reaction will be reported in future work.

\section{THE ACTIVITY}

This paper details an activity used in a practical work module with trainee teachers, working toward a Masters level qualification. The following details the chronological order in which the activities were delivered. Further information relating to these activities is included in the Supporting Information.

\section{Part 1 Introduction: Teacher-Led Session}

At the start of the session, trainees were asked to complete a questionnaire containing:

- a series of open ended questions to capture their thoughts and opinions of IBE,

- for this work, the factors that influence the rate of a chemical reaction.

This information was discussed and shared with the group. Typical answers were rather predictable, with most suggesting the reaction rate increased with concentration of the acid. This hypothesis was used as a starting point for discussion, with the trainees then being asked to develop an experimental procedure to investigate the kinetics of the reaction. Those who shared a similar opinion about the methodology were grouped together to complete the task. General agreement was reached that a range of concentrations of acid should be used to react with a quantity of metal. Teacher involvement at this stage was minimal, but appropriate guidance was given when required.

\section{Part 2 Initialization: Individual Group Work}

Trainees were asked to finally agree on an experimental procedure to investigate the kinetics of the given reaction. In the interest of time, separate groups were asked to prepare at least one concentration of the acid solution in sufficient volume for the remaining groups to share (see Supporting Information). Laboratory support staff were available to give guidance and additional equipment if required.

Different approaches to the task were observed; some groups asked for granulated zinc and used it without weighing out a standard amount; in contrast, others weighed out a specific amount, and finally some of groups used zinc metal plate, measured it precisely, and cut into identical sized pieces.

This part of the activity typically took around $45 \mathrm{~min}$ before moving onto the experimental work. Interestingly, all groups planned to use the lowest concentration of acid first.

\section{Part 3: Measurement of Reaction Rate}

During the six years this activity has been carried out, several different approaches to the task have been observed. Three of most common are reported here.

(1) Groups qualitatively observed the rate gas bubbles were produced in the test tube, focusing specifically on the area around the zinc at each different concentrations of acid. Photographs of the reaction at the most vigorous point were taken and subsequently compared to develop a conclusion.

(2) Groups who were aware of the identity of the gaseous product of the reaction attempted to collect the gas using an inverted test tube. After an agreed period of time that was constant for all concentrations, the mouth of the test tube was covered and ignited with a lit wooden splint.
The subsequent "squeaky pop sound" was evidence that hydrogen gas was produced; the intensity of this sound was estimated to give an indication of the rate of the reaction.

(3) A quantitative approach involved groups using boiling tubes or Erlenmeyer flasks, connected via a rubber bung to a gas-pressure sensor. At that point, the zinc was added to the acid, the tube or flask was sealed with a bung, and the pressure change observed. This same was repeated for each of the concentrations of sulfuric acid.

\section{Part 4: Reporting}

Following the practical work, groups were asked to prepare a short report consisting of restating their hypothesis, describing their methodology, including how the different concentrations of acid were produced, their results, and finally, formulating a conclusion. An opportunity was given to discuss the results and the limitations of their own experimental procedure. This section was typically teacher led and followed with the post laboratory questions, as given in the Supporting Information for teachers.

The results from the quantitative work were shared with the group, as shown in Figure 1.

The groups attempted to explain the results, particularly the unexpected behavior of various acid solutions of concentration $40 \%$ and higher (for the clarity the results for $60,70,80,90$, and $96 \% \mathrm{H}_{2} \mathrm{SO}_{4}$ concentrations were not included in Figure 1).

Reasons for the observed phenomena were proposed, with a common approach involving the problems of acid dissociation and the true reason why acids are acidic. The two equations, ( 1 and 2) were typically included as part of this discussion:

$$
\begin{aligned}
& \text { Dissociation: } \mathrm{H}_{2} \mathrm{SO}_{4}+2 \mathrm{H}_{2} \mathrm{O} \rightarrow 2 \mathrm{H}_{3} \mathrm{O}^{+}+\mathrm{SO}_{4}{ }^{2-} \\
& \text { Redox reaction: } \mathrm{Zn}+2 \mathrm{H}_{3} \mathrm{O}^{+} \rightarrow \mathrm{Zn}^{2+}+\mathrm{H}_{2}+2 \mathrm{H}_{2} \mathrm{O}
\end{aligned}
$$

\section{HAZARDS}

As this work involved working with concentrated acid, students must be aware of the precautions required during the acid dilution. Also, personal protective equipment such as a lab coat, safety goggles, and gloves were expected to be worn during the practical. The gas sensor, as well as the computer or tablet device, should be protected against spills and used only when the reaction rate is measured.

\section{ACTIVITY ASSESSMENT, RESULTS AND DISCUSSION}

As mentioned in Part 1, prior to starting the investigation, the group was given a set of questions relating to IBE and rates of reaction. Upon completion of the practical work, they were asked to revisit these questions, and if their answers had changed, to write any revisions in a different colored pen. In doing this, we received an interesting comparison that captured some impact of the proposed activity. The answers were analyzed using a simple open coding technique. ${ }^{27}$

Direct exposition of the trainee teachers into the role of students had a positive effect on their understanding of IBE, similar to the findings of Banchi and Bell. ${ }^{28}$ The trainees were broadly familiar with the core concept but not all the supporting facets. After the activity, the comments made by the trainees were reviewed. Some clearly demonstrated impact due to the activity, for example, one participant wrote, "I have always written the 


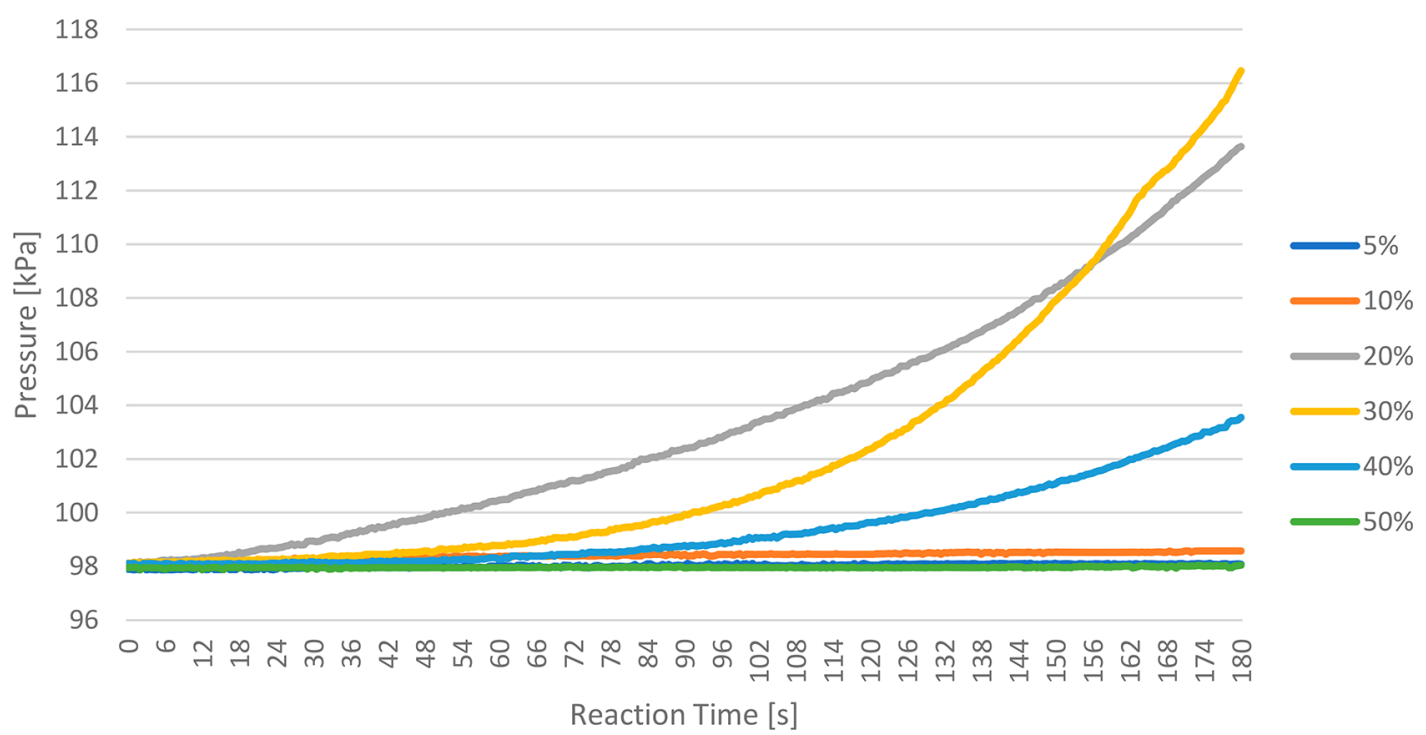

Figure 1. Values of gas pressure in the $100 \mathrm{~mL}$ Erlenmeyer's flask during the reactions of $2 \mathrm{~g}$ zinc metal plates with $20 \mathrm{~mL}$ sulfuric acid of particular concentrations.

results down, and that signaled the end of my work, now I see there is more to do".

Other feedback mentioned being motivated by the unexpected problem in terms of "actually needing to think during the lab, and the necessity to plan the experiment properly". Several of the trainees gave similar comments such as "I never thought how difficult it is not to have any "cook book" guidance. It made me think a lot" and "At first, I did not know what to do when the result was not what I expected. It made me wonder what was happening and I was so motivated that nothing would stop me. I think it must be the same for the students".

Despite these positive comments, there were also several concerns expressed by group, specifically relating to the time take to undertake such an activity. For example, "I can see it working with students, nevertheless I doubt I will have time to prepare such an activity." or "I think it takes too much time leaving little time for actual teaching." It was obvious that some of the students did not quite understand the benefit of IBE and favored a traditional, instructive approach. It is possible to argue that these trainee teachers need further evidence about the effect of inquirybased education before adopting it. ${ }^{29}$ Another concern referred to their students' skills, "I know I have only limited experience, however the students I teach would not know what to do without proper guidance." or "The activity could work for a quarter of an hour, then the students might get lost in the freedom they have, and probably do not use the time well and not able to finish the task." These responses show that the levels of inquiry ${ }^{28}$ need to be explained further, and IBE needs to be presented as an evolving process, not a ready-to-use method at any level in any grade.

Many traditional chemistry experiments or practical activities are designed to allow students to follow a set of procedures without an actual need to think. ${ }^{30,31}$ The purpose of these activities is to help develop laboratory skills. However, in our example, the activity was undertaken by trainee teachers who already had a fundamental understanding of laboratory skills and techniques, which in theory would give them more time to think about their observations. That said, the unexpected result with higher concentrations of acid created a cognitive challenge and encouraged critical thinking.
As a result of this study, there were several areas worth an additional comment. The first related to the experimental procedure developed to investigate the hypothesis. Often the concentrations of acid to test, and the method of measuring the reaction rate, showed a range of responses. In this example, a variation in the type of zinc used (typically granular or zinc metal plate) was also observed.

The second important aspect relates to student motivation. Provided with the problem, the participants might start the work enthusiastically, but a teacher would need to identify groups who need support and guidance to help maintain their focus. This relates to the concerns raised about IBE being able to capture students' motivation for the duration of the entire activity.

The third point relates to using the gas-pressure sensor. When using $\mathrm{H}_{2} \mathrm{SO}_{4}$ solutions in the range $20-40 \%$, the evolution of hydrogen gas was so fast, the rubber bung could be pushed out forcefully. This does not need to be particularly hazardous unless the bung was fitted too tightly. For this reason, the Erlenmeyer flask or larger test tube was recommended. This could probably be a cause of the apprehension in giving students a degree of autonomy and independence in the lab.

\section{CONCLUSION}

This guided-inquiry experiment introduced trainee teachers to a problem with a seemingly simple response, investigating one of the main factors influencing the rate of a chemical reaction. The disconnect between their expectations and the actual observations gave this work a strong motivational potential. The experiment aimed to develop a range of skills, especially the ability to inquire and organize inquiry-based activities in their future professional practice. Nevertheless, not all the students who completed this activity expressed their full understanding and appreciated the benefit of the inquiry-based method.

This study offered more than an investigation of the reaction rate. It gave trainee teachers an opportunity to experience firsthand some of the problems and issues facing a class of chemistry students when undertaking an inquiry based task. Further areas of study could be drawn from this work, for example, an additional dimension could involve investigating the products formed in the reaction. 


\section{ASSOCIATED CONTENT}

\section{S Supporting Information}

The Supporting Information is available on the ACS Publications website at DOI: 10.1021/acs.jchemed.7b00110.

Material for students (PDF, DOCX)

Instructor notes(PDF, DOCX)

\section{AUTHOR INFORMATION}

\section{Corresponding Author}

*E-mail: martin.rusek@pedf.cuni.cz. ORCID

Martin Rusek: 0000-0002-6919-9076

Notes

The authors declare no competing financial interest.

\section{ACKNOWLEDGMENTS}

This work has been supported by Charles University Research Centre Program No. UNCE/HUM/024.

\section{REFERENCES}

(1) PISA 2012 Results: What Students Know and Can Do - Student Performance in Mathematics, Reading and Science; OECD Publishing: Paris, 2014; p 564. http://www.keepeek.com/Digital-AssetManagement/oecd/education/pisa-2012-results-what-students-knowand-can-do-volume-i-revised-edition-february-2014_9789264208780en\#page1.

(2) Bybee, R.; McCrae, B.; Laurie, R. PISA 2006: An Assessment of Scientific Literacy. J. Res. Sci. Teach. 2009, 46 (8), 865-883.

(3) Beneš, P.; Rusek, M.; Kudrna, T. Tradice a současný stav pomůckového zabezpečení edukačního chemického experimentu $\mathrm{v}$ Ceské republice. Chemické Listy 2015, 109 (2), 159-162.

(4) Young People's Views on Science Education: Science Education Tracker Research Report; Kantar Public: London, UK, 2017; https:// wellcome.ac.uk/sites/default/files/science-education-tracker-reportfeb17.pdf (accessed February 2018).

(5) Rocard, M.; Csermely, P.; Jorde, D.; Lenzen, D.; WalbergHenriksson, H.; Hemmo, V. Science Education Now: A Renewed Pedagogy for thee Future of Europe; European Commission: Brusel, 2007; p 28.

(6) Murphy, C.; Murphy, C.; Kilfeather, P. Children Making Sense of Science. Research in Science Education 2011, 41 (2), 283-298.

(7) Bernard, P.; Maciejowska, I.; Krzeczkowska, M.; Odrowąż, E. Influence of In-service Teacher Training on their Opinions about IBSE. Procedia-Social and Behavioral Sciences 2015, 177, 88-99.

(8) Carraher, J. M.; Curry, S. M.; Tessonnier, J. P. Kinetics, Reaction Orders, Rate Laws, and Their Relation to Mechanisms: A Hands-On Introduction for High School Students Using Portable Spectrophotometry. J. Chem. Educ. 2016, 93 (1), 172-174.

(9) Kjonaas, R. A.; Tucker, R. J. F. A discovery-based experiment involving rearrangement in the conversion of alcohols to Alkyl Halides. J. Chem. Educ. 2008, 85 (1), 100-101.

(10) Sulcius, A. Reactions of Metals in Nitric Acid: Writing Equations and Calculating Electromotive Force of Redox Reaction. J. Chem. Educ. 2015, 92 (12), 1971-1972.

(11) Mullins, C. Guided-inquiry project-based experiments in the undergraduate organic chemistry lab. Abstracts of Papers of the American Chemical Society 2013, 246.

(12) Pastre, I. A.; Plicas, L. M. D.; Tiera, V. A. D.; Custodio, J. V.; Agostinho, S. M. L. Acid-base Reactions: Concept, Representation and Generalization from the Energy Involved in Transformations. Quim. Nova 2012, 35 (10), 2072-2075.

(13) Sandi-Urena, S.; Cooper, M. M.; Gatlin, T. A.; Bhattacharyya, G. Students' experience in a general chemistry cooperative problem based laboratory. Chem. Educ. Res. Pract. 2011, 12 (4), 434-442.
(14) Bradley, J. D.; Mosimege, M. D. Misconceptions in acids and bases: A comparative study of student teachers with different chemistry backgrounds. South African Journal of Chemistry 1998, 51 (3), 137-143.

(15) Hapkiewicz, A. M. Misconceptions in Chemistry. Abstracts of Papers of the American Chemical Society 1995, 210, 97-CHED.

(16) Robinson, W. R. Misconceptions in Chemistry - How and why they interfere with learning. Abstracts of Papers of the American Chemical Society 1991, 201, 194-CHED.

(17) Taber, K. Chemical Misconceptions: Prevention, Diagnosis, and Cure; Royal Society of Chemistry: London, 2002; Vol. 1.

(18) Luckie, D. B.; Maleszewski, J. J.; Loznak, S. D.; Krha, M. Infusion of collaborative inquiry throughout a biology curriculum increases student learning: a four-year study of "Teams and Streams. Advances in Physiology Education 2004, 28 (4), 199-209.

(19) Chairam, S.; Klahan, N.; Coll, R. K. Exploring Secondary Students' Understanding of Chemical Kinetics through Inquiry-Based Learning Activities. Eurasia Journal of Mathematics Science and Technology Education 2015, 11 (5), 937-956.

(20) Sözbilir, M.; Pinarbaşi, T.; Canpolat, N. Prospective chemistry teachers' conceptions of chemical thermodynamics and kinetics. Eurasia Journal of Mathematics, Science and Technology Education 2010, 6 (2), 111-121.

(21) Liebermann, J. Using Kinetics Experiments from the Journal of Chemical Education as the Basis for High-school Scoence Projects. J. Chem. Educ. 1988, 65 (12), 1067-1069.

(22) Demircioglu, G.; Ayas, A.; Demircioglu, H. Conceptual change achieved through a new teaching program on acids and bases. Chem. Educ. Res. Pract. 2005, 6 (1), 36-51.

(23) Mills, K. V.; Guilmette, L. W. Thermochemical Analysis of Neutralization Reactions: An Introductory Discovery Experiment. J. Chem. Educ. 2007, 84 (2), 326.

(24) DeMeo, S. Does Copper Metal React with Acetic Acid? J. Chem. Educ. 1997, 74 (7), 844.

(25) Eminah, J. A reaction between zinc and concentrated sulfuric acid to produce hydrogen sulfide. School Science Review 2009, 91 (334), 20-22.

(26) Yang, S. P. How many atomic layers of zinc are in a galvanized iron coating? An experiment for general chemistry laboratory. J. Chem. Educ. 2007, 84 (11), 1792-1794.

(27) Given, L. The SAGE Encyclopedia of Qualitative Research Methods; SAGE Publications Ltd.: Thousand Oaks, CA, 2008.

(28) Banchi, H.; Bell, R. The Many Levels of Inquiry. Science and Children 2008, 46 (2), 26-29.

(29) Rusek, M.; Stárková, D.; Chytrý, V.; Bílek, M. Adoption of ICT Innovations by Secondary School Teachers and Pre-Service Teachers within Chemistry Education. J. Baltic Sci. Educ. 2017, 16 (4), 510-523. http://oaji.net/articles/2017/987-1503904959.pdf (accessed February 2018).

(30) van den Berg, E. The PCK of Laboratory Teaching: Turning Manipulation of Equipment into Manipulation of Ideas. Scientia in Educatione 2013, 4 (2), 74-92.

(31) Wang, J. J.; Rodríguez Núñez, J. R.; Maxwell, J. E.; Algar, W. R. Build Your Own Photometer: A Guided-Inquiry Experiment to Introduce Analytical Instrumentation. J. Chem. Educ. 2016, 93, 166171. 